\title{
Tonantzitlolone A and other cytotoxic constituents of Sapium macrocarpum (Euphorbiaceae)
}

\author{
Fernando Novillo, ${ }^{1,2}$ Verónica Rosero, ${ }^{1,2}$ María Isabel Chávez, ${ }^{1}$ Simón Hernández-Ortega, ${ }^{1}$ \\ Esteban M. Martínez, ${ }^{3}$ Guillermo Delgado*1 \\ 1 Instituto de Química, Universidad Nacional Autónoma de México. Circuito Exterior, Ciudad Universitaria. Coyoacán 04510. \\ Ciudad de México, México. delgado@unam.mx; tel.: +5255-5622-4446 \\ 2 Facultad de Ciencias Químicas, Universidad Central del Ecuador. Francisco Viteri s/n y Gato Sobral. Quito-Ecuador. \\ 3 Instituto de Biología, Universidad Nacional Autónoma de México, Ciudad Universitaria. Coyoacán 04510. Ciudad de México, \\ México.
}

Received November 30 $0^{\text {th }}, 2016$; Accepted February $13^{\text {th }}, 2017$.

\begin{abstract}
Sapium macrocarpum (Euphorbiaceae) is a tropical tree located mainly in the southern part of Mexico and in Central America, and it is used in the Mayan traditional medicine for the treatment of several skin diseases. The dichloromethane- $\mathrm{MeOH}$ extract of the aerial parts displayed cytotoxic activity against certain cancer cell lines. Lupeol (1), lupenone (2), sitostenone (3), $\beta$-sitosterol (4), stigmasterol (5), sitosteryl $\beta$-D-glucopyranoside (6) and the rare diterpene tonantzitlolone A (7) were characterized from this extract. The structural analysis allowed the ${ }^{1} \mathrm{H}$ NMR reassignments for $\mathrm{H}-12 \alpha$ and $\mathrm{H}-12 \beta$, and for $\mathrm{H}-13 \alpha$ and $\mathrm{H}-13 \beta$ of tonantzitlolone $\mathrm{A}$ (7). The cytotoxic activity of compounds 1-3, 6 and 7 was evaluated against selected cancer cell lines. Compounds 3, 6 and 7 displayed clear activity against K562 (leukemia). This is the first report on the chemical constituents of $S$. macrocarpum, and points out that this species is an additional source of tonantzitlolone A. Compound 7 has only been reported previously from species of the Stillingia, Sebastiania and Sapium genera, which belong to the Hippomaninae subtribe of the family Euphorbiaceae.

Keywords: sitostenone; diterpenes; flexibilane; Euphorbiaceae; NMR reassignments, cytotoxicity.
\end{abstract}

\section{Introduction}

Sapium is a cosmopolitan genus of the Euphorbiaceae plant family which includes 23 accepted names of species, consolidated from 254 former names of synonyms. Several species of this genus have been used in traditional medicine in several parts of the world for treating wounds, snake bites, and skin-related diseases, among other ailments [1,2]. From Sapium species collected in Asia, phenolic compounds were identified as constituents of $S$. insigne [3,4], S. sebiferum [5,6]; phorbol esters were identified as secondary metabolites of $S$. indicum [7,8] and $S$. insigne [3,9]; and the alkaloid bukittinggine and triterpenes were identified as constituents of $S$. baccatum [1012]. Among species collected in the American continent, terpenoids have been isolated from $S$. rigidifolium [13] and $S$. haematospermum [14], and coumarins from S. sebiferum [15].

S. macrocarpum is a tree native mainly to the southern part of Mexico and Central America. It is used in Mayan traditional
Resumen: Sapium macrocarpum (familia Euphorbiaceae) es un árbol localizado en la parte central de México y en Sudamérica, el cual es usado en la medicina tradicional Maya para el tratamiento de diversas enfermedades de la piel. El extracto de diclorometano-metanol de las partes aéreas de esta especie mostró actividad inhibitoria de la proliferación de ciertas células cancerosas humanas. Lupeol (1), lupenona (2), sitostenona (3), $\beta$-sitosterol (4), estigmasterol (5), $\beta$-D-glucopiranósido de sitosterilo (6) y el diterpeno relativamente raro tonantzitlolona A (7) fueron caracterizados de este extracto. El análisis estructural de la tonantzitlolona A (7) permitió la reasignación de las señales de $\mathrm{RMN}{ }^{1} \mathrm{H}$ de $\mathrm{H}-12 \alpha$ y $\mathrm{H}-12 \beta$, y de $\mathrm{H}-13 \alpha$ y $\mathrm{H}-13 \beta$. La actividad citotóxica de los compuestos 1-3, 6 y 7 fue evaluada frente a las líneas celulares cancerosas selectas. Los compuestos 3, 6 y 7 mostraron actividad clara contra K562 (leucemia). Este es el primer reporte sobre los constituyentes químicos de $S$. macrocarpum, encontrando que esta especie constituye una fuente adicional de tonantzitlolona A. El compuesto 7 ha sido aislado de los géneros Stillingia, Sebastiania y Sapium, los cuales pertenecen a la subtribu Hippomaninae de la familia Euphorbiaceae.

Palabras clave: sitostenona; diterpenos; flexibilano; Euphorbiaceae; reasignaciones de RMN, citotoxicidad.

medicine to cure skin infections, and particularly, for treating warts [16]. It has not been chemically analyzed previously, but some phytotoxic compounds have been isolated from an endophytic fungus of this species [17]. Here we report the chemical constituents isolated from an extract of the aerial parts of $S$. macrocarpum, which displayed cytotoxicity in selected tumor cell lines. We identified tonantzitlolone A (7), an uncommon diterpene with a flexibilane skeleton, together with a series of known compounds, and determined their cytotoxicities.

\section{Results and Discussion}

The ${ }^{13} \mathrm{C}$ NMR spectrum of compound $\mathbf{1}$ showed 30 signals which were defined by DEPT experiments. The results showed seven methyl groups, eleven methylenes (one vinylic methylene), six methines (one oxymethine), and six quaternary carbons. The ${ }^{1} \mathrm{H}$ NMR spectrum displayed six singlets for methyl 
groups between $\delta_{\mathrm{H}} 1.03$ and $\delta_{\mathrm{H}} 0.76$, and one methyl group at $\delta_{\mathrm{H}} 1.68$; the latter signal belonged to an isopropenyl fragment, consistent with the presence of the vinylic methylene mentioned above. These NMR data were identical to those reported for lupeol (1) [18], and a direct comparison with an authentic sample confirmed its structure. The less polar fractions of the chromatogram provided a white solid. Its ${ }^{13} \mathrm{C}$ NMR spectrum also displayed 30 signals that included a carbonyl group of a ketone $\left(\delta_{\mathrm{C}} 218.40\right)$ and signals with chemical shifts similar to those for $\mathbf{1}$, but did not show the oxymethine observed for $\mathbf{1}\left(\delta_{\mathrm{C}}\right.$ 79.02). The EIMS showed a molecular ion at $\mathrm{m} / z 424$ in agreement with the molecular formula $\mathrm{C}_{30} \mathrm{H}_{48} \mathrm{O}$. The ${ }^{13} \mathrm{C}$ NMR data and its physical constants were identical to those reported for lupenone (2), confirming its structure [19]. Four structurally related compounds were isolated, whose ${ }^{1} \mathrm{H}$ and ${ }^{13} \mathrm{C}$ NMR data indicated the presence of four tertiary methyls, three secondary methyls and one primary methyl, characteristic for phytosterols. Sitostenone (3) [20,21], $\beta$-sitosterol (4), stigmasterol (5) [22] and $\beta$-sitosteryl $\beta$-D-glucopyranoside (6) [23] were characterized. The identities of these compounds were confirmed by comparing their ${ }^{1} \mathrm{H}$ and ${ }^{13} \mathrm{C}$ NMR data and their physical constants with those published in the literature, and with authentic samples available in our laboratory.

The molecular formula of $\mathrm{C}_{26} \mathrm{H}_{40} \mathrm{O}_{7}$ for metabolite 7, was established from the analysis of its NMR and EIMS data. The ${ }^{13} \mathrm{C}$ NMR spectra (Table 1) exhibited 26 carbon signals, which comprised seven methyl groups (three tertiary, two secondary, one primary and one vinylic), four methylenes, nine methines (four bonded to oxygen, three olefinic, and two aliphatic), and six non-protonated carbons (two carbonyls, one olefinic, one aliphatic, one bonded to oxygen, and one bonded to two oxygens). The presence of a methyl senecioate fragment $\left(\mathrm{C}_{6} \mathrm{H}_{9} \mathrm{O}_{2}\right)$ was established by the ${ }^{13} \mathrm{C}$ and ${ }^{1} \mathrm{H}$ NMR signals assigned (by $\mathrm{HMBC}$ analysis) to an ester carbonyl $\left(\delta_{\mathrm{C}} 166.58\right)$ bonded to the olefinic methine $\left(\delta_{\mathrm{C}} 113.86, \delta_{\mathrm{H}} 5.70\right)$ of a trisubstituted double bond $\left(\delta_{\mathrm{C}} 162.97\right)$, having an ethyl $\left(\delta_{\mathrm{C}} 33.88, \delta_{\mathrm{H}} 2.17 ; \delta_{\mathrm{C}} 11.83\right.$, $\left.\delta_{\mathrm{H}} 1.07\right)$ and a methyl group $\left(\delta_{\mathrm{C}} 18.99, \delta_{\mathrm{H}} 2.16\right)$ as the other substituents. Therefore, this compound was a diterpene with five degrees of unsaturation bonded to a methyl senecioate fragment. The presence of a $\beta, \gamma$-unsaturated- $\alpha$-methyl ketone fragment was deduced from the ${ }^{13} \mathrm{C}$ and ${ }^{1} \mathrm{H}$ NMR signals of a ketone $\left(\delta_{\mathrm{C}} 211.30\right)$ bonded to a methine $\left(\delta_{\mathrm{H}} 3.34\right.$, according to HMBC correlation), which was further linked to a methyl group $\left(\delta_{\mathrm{C}} 16.00, \delta_{\mathrm{H}} 1.12, \mathrm{HMBC}\right.$ and COSY correlations) and to a trans disubstituted double bond $\left(\delta_{\mathrm{C}} 126.81, \delta_{\mathrm{H}} 5.24 ; \delta_{\mathrm{C}} 140.07\right.$, $\delta_{\mathrm{H}}$ 5.86). In addition, the remaining ${ }^{1} \mathrm{H}$ and ${ }^{13} \mathrm{C}$ NMR signals, particularly those for two aliphatic methylenes, three oxymethines, and one hemiketal carbon, were consistent with the presence of a $\delta$-lactol and a tetrahydrofuran in the diterpene skeleton. The NMR data were almost identical to those reported for tonantzitlolone (7, named so after the Aztec goddess Tonantzin, by Dr. X. A. Domínguez), a metabolite previously isolated from Stillingia sanguinolenta, an endemic plant used traditionally in northern Mexico [24]. However, a number of inconsistencies in the reported ${ }^{1} \mathrm{H}$ NMR assignments were detected, particularly those for the $\mathrm{H}-12 \alpha$ and $\mathrm{H}-12 \beta$, and the
$\mathrm{H}-13 \alpha$ and $\mathrm{H}-13 \beta$ [25-27]. The correct assignments are shown in Table 1. These assignments were based on the analysis of the coupling constants between the hydrogens of the tetrahydrofuran ring, which indicated that the observed $J_{12 \alpha, 13 \beta}=0$ (not informed in references 24-27) was in agreement with the $E_{2}$ arrangement of the conformational itinerary of an oxolane ring [28]. Consequently, some reported NOESY correlations should also be corrected according to the new assignments. For instance, the NOESY crosspeak between $\mathrm{H}-14\left(\delta_{\mathrm{H}} 3.77\right)$ and the signal at $\delta_{\mathrm{H}} 2.45$ informed by Lima [26], was not detected, instead, a correlation between $\mathrm{H}-14$ and $\mathrm{H}-13 \beta\left(\delta_{\mathrm{H}} 1.77\right)$ was clearly observed. Some minor inconsistencies were due to the use of different numbering systems for the macrocycle, in addition to the fact that one of the first structures published was later corrected [29]. Selected relevant NOESY correlations are illustrated in the X-ray structure depicted in Figure 1(a), since the conformation determined by X-ray analysis (vide infra) was in agreement with the $\mathrm{H}-\mathrm{H}$ dihedral angles deduced from the $J_{\mathrm{H}-\mathrm{H}}{ }^{1} \mathrm{H}$ NMR coupling constants. Some fragments of this compound were previously synthesized [30], the total synthesis has also been completed [24,31], and its absolute configuration has been established [32], as depicted in formula 7 .

An X-ray analysis of compound 7 confirmed the molecular connectivity and the absolute configuration. In addition, we could identify two intramolecular hydrogen bonds: one between $\mathrm{OH}-9$ and the tetrahydrofuranic oxygen, and the second between $\mathrm{OH}-10$ and the pyranyl oxygen (Figure 1(b)). On the basis of these findings, the structure of $\mathbf{7}$ could be considered to have some rigidity, which further supported the observed ${ }^{1} \mathrm{H}-{ }^{1} \mathrm{H}$ NMR coupling constants, consistent with the conformation of the metabolite in the solid state. The absolute configuration for this compound was the same as that obtained for a compound isolated from Stillingia lineata (Euphorbiaceae) in the search of antichikunguya agents; and thus, compound 7 was renamed by Grondin et al. as tonantzitlolone A [27], since Kirshning et al. previously characterized an structural variant with difference in the ester side chain, named tonantzitlolone B [25].

The inhibitory activities of the extract of Sapium macrocarpum and of compounds 1-3, 6, and 7 were tested against U251, PC-3, K562, HCT-15, MCF-7, and SKLU-1 human tumor cell lines using the protein-binding dye sulforhodamine B (SRB) microculture assay to measure cell growth [33]. The results revealed that the extract (at $50 \mu \mathrm{g} / \mathrm{mL}$ ) and the assayed compounds (at $50 \mu \mathrm{M}$ ) displayed differential activity (Table 2). Lupeol (1) exhibited clear activity against PC-3 cells, and all the natural compounds $(\mathbf{1 - 3}, \mathbf{6}$ and $\mathbf{7})$ were active against the leukemia cell line (K562). $\beta$-Sitosteryl $\beta$-D-glucopyranoside (6) displayed the highest activity in the K562 cell line (77\% of inhibition), consistent with results with other leukemia cells (CEM/ADR5000) [34]. However, evaluations of these pure compounds against other tumor cell lines indicated inhibitory activities below $40 \%$. Sitostenone (3) was previously reported to possess anti-proliferation and anti-tyrosinase activities in melanoma cells [35]. The activities displayed by tonantzitlolone A (7) were similar to those reported previously for tonantzitlolones B-F [36]. Recently, tonantzitlolone A (7) was 

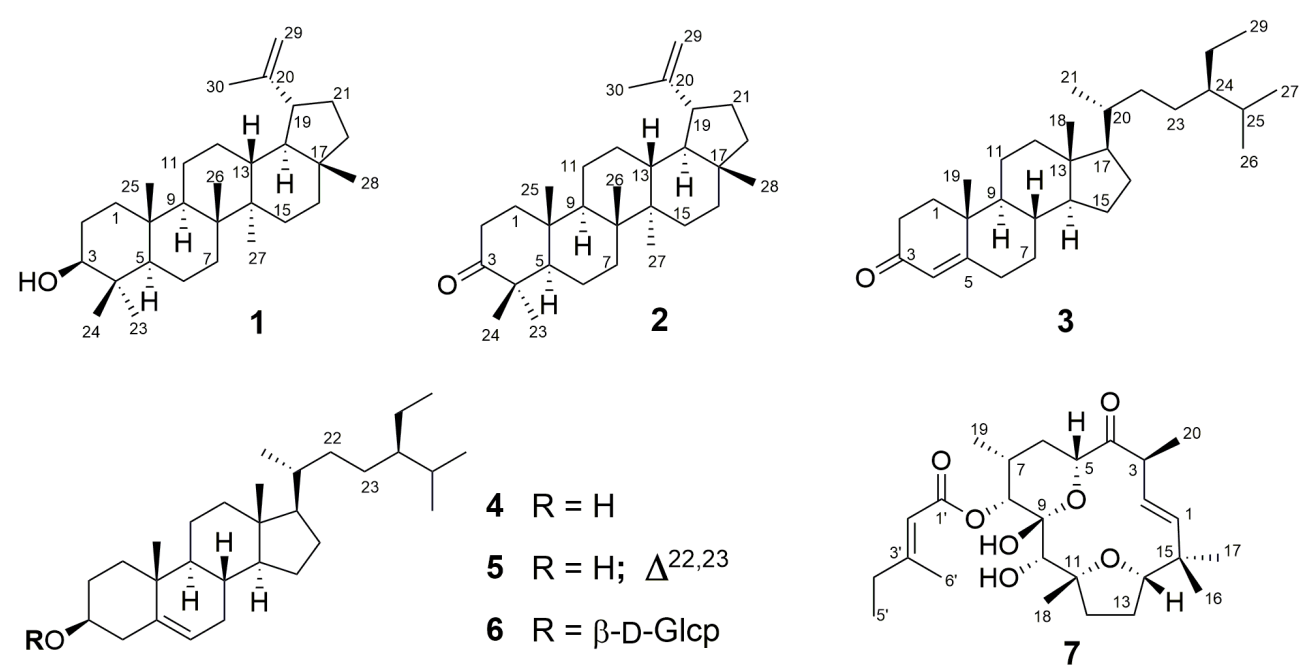

Table 1. ${ }^{1} \mathrm{H}(400 \mathrm{MHz})$ and ${ }^{13} \mathrm{C}$ NMR $(100 \mathrm{MHz})$ data of 7 ( $\delta$ in ppm, $J$ in $\left.\mathrm{Hz}, \mathrm{CDCl}_{3}\right)$

\begin{tabular}{|c|c|c|c|c|c|}
\hline Position & $\delta_{\mathrm{H}}, \mathbf{m}$ & $J(\mathrm{~Hz})$ & $\delta_{\mathbf{C}}$ & NOESY & $\operatorname{HMBC}(\mathrm{H} \rightarrow \mathrm{C})$ \\
\hline 1 & $5.86, \mathrm{~d}$ & $J_{1,2} 15.2$ & 140.07 & $13 \alpha, 3,17$ & $\begin{array}{c}\mathrm{C} 2, \mathrm{C} 3, \mathrm{C} 14, \mathrm{C} 15, \\
\mathrm{C} 17\end{array}$ \\
\hline 2 & $5.24, \mathrm{dd}$ & $J_{1,2} 15.2, J_{2,3} 9.6$ & 126.81 & $16,3,5$ & $\mathrm{C} 3, \mathrm{C} 4, \mathrm{C} 15$ \\
\hline 3 & $3.34, \mathrm{dq}$ & $J_{2,3} 9.6, J_{3,20} 6.8$ & 49.53 & 20 & $\mathrm{C} 1, \mathrm{C} 2, \mathrm{C} 4, \mathrm{C} 20$ \\
\hline 4 & & & 211.30 & & \\
\hline 5 & $4.63, \mathrm{dd}$ & $J_{5,6 \alpha} 12, J_{5,6 \beta} 2.9$ & 74.14 & $6 \beta, 7$ & $\mathrm{C} 4, \mathrm{C} 6$ \\
\hline $6 \alpha$ & 1.39, ddd & $J_{6 \alpha, 6 \beta} 13.5, J_{6 \alpha, 7} 13.0$ & 28.82 & $19,6 \beta$ & $\mathrm{C} 5, \mathrm{C} 8, \mathrm{C} 19$ \\
\hline $6 \beta$ & 1.85, ddd & $J_{6 \beta, 7} 3.2$ & & $19,6 \alpha, 5,7$ & \\
\hline 7 & 2.34, dddq & $J_{7,8} 2.6, J_{7,19} 6.9$ & 29.05 & $5,8,6 \beta, 19$ & C6, C19 \\
\hline 8 & $4.90, \mathrm{~d}$ & $J_{7,8} 2.6$ & 73.17 & $10,7,19$ & $\mathrm{C} 6, \mathrm{C} 19, \mathrm{C} 9$ \\
\hline 9 & & & 97.14 & & \\
\hline 10 & $3.43, \mathrm{~s}$ & & 78.20 & $12 \alpha, 8,18$ & $\mathrm{C} 9, \mathrm{C} 12, \mathrm{C} 18$ \\
\hline 11 & & & 87.65 & & \\
\hline $12 \alpha$ & $2.45, \mathrm{dd}$ & $\begin{array}{c}J_{12 \alpha, 12 \beta} 12.5, J_{12 \alpha, 13 \alpha} 7.5 \\
J_{12 \alpha, 13 \beta} 0.0\end{array}$ & 37.35 & $12 \beta, 13 \alpha, 10$ & $\mathrm{C} 13, \mathrm{C} 18$ \\
\hline $12 \beta$ & 1.54, ddd & $J_{12 \beta, 13 \beta} 7.5$ & & $18,13 \beta, 12 \alpha$ & \\
\hline $13 \alpha$ & 2.05 , dddd & $\begin{array}{c}J_{13 \alpha, 13 \beta} 12.5, J_{12 \beta, 13 \alpha} 12.5, \\
J_{13 \alpha, 14} 12.5\end{array}$ & 28.06 & $13 \beta, 12 \alpha, 1$ & $\mathrm{C} 12$ \\
\hline $13 \beta$ & 1.77, ddd & $\begin{array}{c}J_{12 \beta, 13 \beta} 7.5, J_{12 \alpha, 13 \beta} 0.0 \\
J_{13 \beta, 14} 5.0\end{array}$ & & $17,12 \beta, 13 \alpha, 14$ & \\
\hline 14 & $3.77, \mathrm{dd}$ & & 88.89 & $13 \beta, 16,17,12 \beta, 18$ & $\underset{\mathrm{C} 17}{\mathrm{C} 1, \mathrm{C} 12, \mathrm{C} 13, \mathrm{C} 16,}$ \\
\hline 15 & & & 38.73 & & \\
\hline 16 & $1.14, \mathrm{~s}$ & & 25.09 & $17,14,2, \mathrm{OH}-9$ & $\mathrm{C} 1, \mathrm{C} 14, \mathrm{C} 15, \mathrm{C} 17$ \\
\hline 17 & $0.91, \mathrm{~s}$ & & 25.44 & $16,13 \beta, 14$ & $\mathrm{C} 1, \mathrm{C} 14, \mathrm{C} 15, \mathrm{C} 16$ \\
\hline 18 & $1.38, \mathrm{~s}$ & & 28.11 & $12 \beta, 10$, OH-9 & $\mathrm{C} 10, \mathrm{C} 11, \mathrm{C} 12$ \\
\hline 19 & $0.85, \mathrm{~d}$ & $J_{7,19} 6.9$ & 17.01 & $7,6 \beta, 6 \alpha$ & C6, C7, C8 \\
\hline 20 & $1.12, \mathrm{~d}$, & $J_{3,20} 6.8$ & 16.00 & 3 & $\mathrm{C} 2, \mathrm{C} 3, \mathrm{C} 4$ \\
\hline 1 , & - & & 166.58 & - & \\
\hline 2 & $5.70, q$ & $J_{2,6}, 1.2$ & 113.86 & $5^{\prime}, 4^{\prime}$ & C4', C6' \\
\hline 3 ' & - & & 162.97 & - & \\
\hline 4 ' & $2.17, \mathrm{q}$ & $J_{4,5}, 7.2$ & 33.88 & 5, & $\mathrm{C} 2^{\prime}, \mathrm{C} 5^{\prime}, \mathrm{C} 6^{\prime}$ \\
\hline 5, & $1.07, \mathrm{t}$ & $J_{4,5}, 7.7$ & 11.83 & 4, & $\mathrm{C} 4$ \\
\hline 6 & $2.16, \mathrm{~d}$ & $J_{2,6}, 1.2$ & 18.99 & 5 & C2', C4' \\
\hline OH-9 & $5.66, \mathrm{~s}$ & & - & $5,10,18$ & $\mathrm{C} 8, \mathrm{C} 9, \mathrm{C} 10$ \\
\hline $\mathrm{OH}-10$ & $3.10, \mathrm{~s}$ & & - & - & - \\
\hline
\end{tabular}


Fernando Novillo et al.

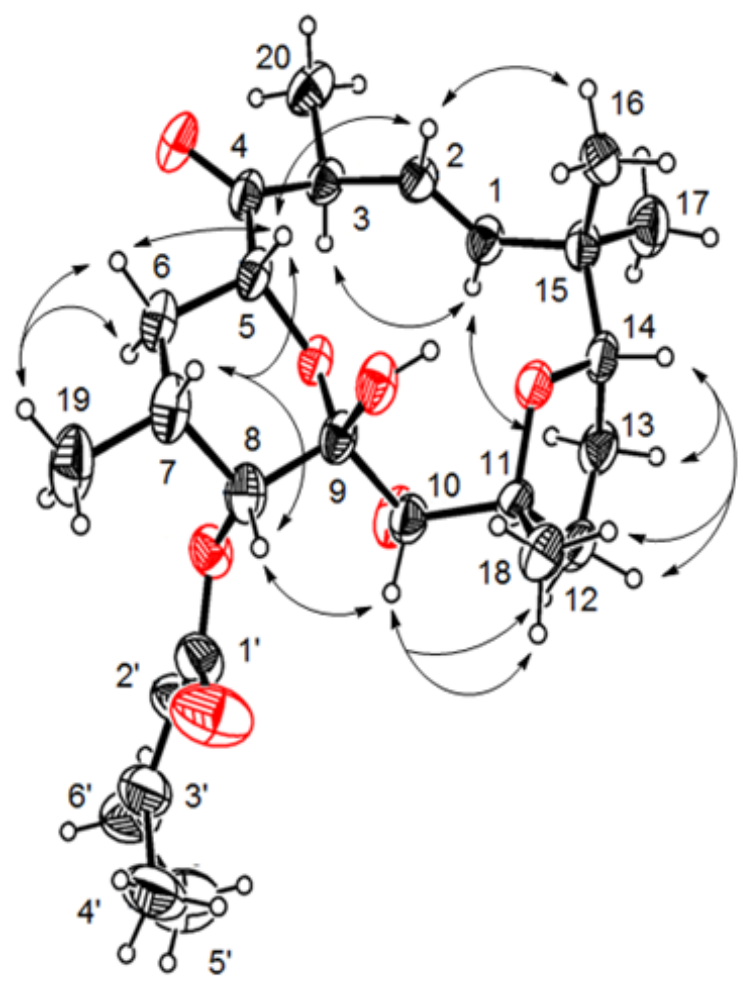

(a)

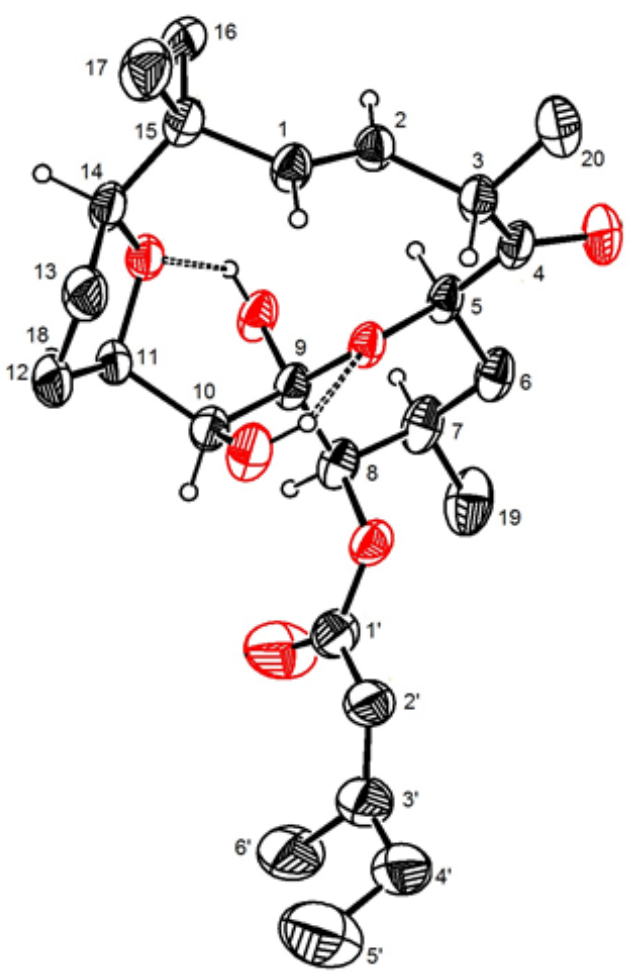

(b)

Figure 1. (a) Selected NOESY correlations of tonantzitlolone A (7) using the drawing derived of the X-ray analysis. (b) X-ray crystal structure of tonantzitlolone A (7) indicating the intramolecular hydrogen bonds (by broken lines).

identified as a potent anti-tumor agent in renal cancer cells as a PKC activator [37], and as a cytostatic compound on tumor cells, inducing monoastral half-spindle formation [38].

Table 2. Cytotoxic activities (\% of inhibition) of the extract and isolated products from $S$. macrocarpum $(50 \mu \mathrm{g} / \mathrm{mL}$ for the extract, $50 \mu \mathrm{M}$ for pure compounds, DMSO as vehicle).

\begin{tabular}{crllccc}
\hline & \multicolumn{6}{c}{ Human tumor cell lines } \\
\hline Sample & U251 & PC-3 & K562 & HCT-15 & MCF-7 & SKLU-1 \\
\hline $\mathrm{CH}_{2} \mathrm{Cl}_{2}-\mathrm{MeOH}$ & 17.5 & 59.8 & 96.5 & 45.3 & 39.5 & 44.6 \\
$(1: 1)$ Extract & & & & & & \\
$\mathbf{1}$ & 27.3 & 50.7 & 48.8 & 10.4 & 22.3 & 13.0 \\
$\mathbf{2}$ & 8.3 & 12.1 & 53.2 & 9.1 & 8.2 & 28.9 \\
$\mathbf{3}$ & 1.5 & 18.4 & 66.1 & 2.8 & 11.6 & 25.9 \\
$\mathbf{6}$ & 11.9 & 32.6 & 77.0 & 12.6 & 2.6 & 27.7 \\
$\mathbf{7}$ & 29.2 & 36.8 & 64.5 & 32.1 & 38.1 & 27.6 \\
Etoposide $^{\mathrm{a}}$ & $91.1^{\mathrm{b}}$ & $51.4^{\mathrm{c}}$ & $60.2^{\mathrm{c}}$ & $80.8^{\mathrm{c}}$ & $56.8^{\mathrm{c}}$ & $81.7^{\mathrm{c}}$ \\
\hline
\end{tabular}

\footnotetext{
${ }^{\text {a }}$ Positive control.

${ }^{\mathrm{b}}$ Concentration at $10 \mu \mathrm{M}$.

${ }^{\mathrm{c}}$ Concentration at $31 \mu \mathrm{M}$.
}

\section{Conclusion}

In our search for bioactive natural products, we found that the extract of S. macrocarpum (collected in the State of Chiapas, Mexico), a plant used in Mayan traditional medicine for the treatment of warts [16], displayed inhibitory activity toward some cancer cell lines. This species had not been previously analyzed, and in the present chemical investigation we characterized compounds 1-7. The ${ }^{1} \mathrm{H}$ NMR analysis of the secondary metabolite 7 allowed the reassignments of the tetrahydrofuran hydrogens. Tonantzitlolone A (7) was previously isolated from a Mexican population of Stillingia sanguinolenta (collected in the State of Nuevo León) [25], and later from Sebastiania macrocarpa (from the Brazilian State of Ceará) [26], and from Stillingia lineata (from La Reunion Island, Indian Ocean, France) [27]. The cytotoxic evaluations of the chemical constituents showed activity and selectivity for some cell lines, although the extract displayed in some cases higher activity, may be due to synergistic interactions. The best cytotoxicities were found with tonantzitlolone A (7) and sitostenone (3), which showed clear activity against a leukemia cell line. The cytotoxicity results for tonantzitlolone A (7) were comparable to those 
found for tonantzitlonones B-F in a previous study [36]. It is interesting to note that flexibilane diterpenes have been characterized from Stillingia, Sebastiania and Sapium species; all these genera belong to the Hippomaninae subtribe, tribe Hippomaneae, subfamily Euphorbioideae of the family Euphorbiaceae [39].

\section{Experimental}

\section{General Experimental Procedures}

Analytical TLC was carried out on precoated silica gel $60 \mathrm{~F}_{254}$ sheets (Merck), and revealed with cerium ammonium sulfate (1\%) in sulfuric acid $2 \mathrm{~N}$. For preparative chromatography (PLC) were used glass plates $(20 \times 20 \mathrm{~cm})$ on precoated silicagel $60 \mathrm{~F}_{254}, 2 \mathrm{~mm}$ (Merck). Column chromatography (CC) was performed using silica gel (230-400 mesh). All solvents were dried and distilled before use. Melting points were determined on a Fisher Johns apparatus (Cole Parmer) and are uncorrected. ${ }^{1} \mathrm{H}(400 \mathrm{MHz}),{ }^{13} \mathrm{C}(100.0 \mathrm{MHz})$, and 2D NMR spectra (in $\mathrm{CDCl}_{3}$ ) were obtained on Bruker Avance III NMR 400 spectrometer. Chemical shifts were expressed in parts per million $(\boldsymbol{\delta})$ relative to TMS as internal standard. EIMS were taken in a JEOL JMS-AX 505 HA. Analysis by X-ray diffraction was performed using a Bruker D8 Venture automatic diffractometer with a CCD area detector at 173(2) K using Helios multilayer mirror $\mathrm{Cu} \mathrm{K} \alpha$ radiation $(\lambda=1.54178 \AA)$.

\section{Plant material, extraction and isolation}

The aerial parts of S. macrocarpum Müll. Arg. was collected in Arriaga district, in the state of Chiapas, Mexico, in 2007. Prof. Esteban M. Martínez identified the plant material and a voucher specimen (39273 Esteban M. Martínez) was deposited in the collection of the National Herbarium (MEXU), Instituto de Biología, UNAM.

Aerial parts of S. macrocarpum (leaves and branches, 1.1 $\mathrm{kg}$ ) were dried, powdered and extracted three times at room temperature with a mixture of $\mathrm{CH}_{2} \mathrm{Cl}_{2}-$ methanol (1:1), and a residue $(41 \mathrm{~g})$ was obtained after evaporating the solvent under reduced pressure. Part of this residue ( $38 \mathrm{~g}$ ) was adsorbed in a 1:1 mixture of celite and silica gel $(30 \mathrm{~g})$ and chromatographed over a silica gel column eluted with hexane-EtOAc mixtures of increasing polarity, yielding 130 eluates which were joined in eight main fractions (A-H), according TLC analyses. Fraction D (124 mg) was subjected to column chromatography over silica gel with hexane-EtOAc gradient system, to give a fraction that was further purified by preparative TLC eluted with a mixture of hexane-EtOAc $(85: 15)$, yielding lupenone $(2,15 \mathrm{mg})$. (Rf 0.69, hexane-EtOAc, 85:15). EIMS $m / z$ (\% rel): $424\left(\mathrm{M}^{+}\right.$, 6), 355 (4), 313 (4), 245 (3), 232 (4), 205 (100), 189 (30), 109 (60), 95 (58), 69 (45), $67(47) .{ }^{1} \mathrm{H}$ NMR $\left(\mathrm{CDCl}_{3}, 400 \mathrm{MHz}\right): \delta$ $4.63(1 \mathrm{H}, \mathrm{d}, J=2.4 \mathrm{~Hz}, \mathrm{H}-29 \mathrm{~b}), 4.50(1 \mathrm{H}, \mathrm{dd}, J=2.6,1.4 \mathrm{~Hz}$, H-29a), 2.35 (1H, m, H-19), 1.62 (3H, s, H-30), 1.50 (1H, s, $\mathrm{H}-2 \mathrm{~b}), 1.37$ (1H, s , H-11), $1.00\left(3 \mathrm{H}, \mathrm{s}, \mathrm{CH}_{3}-26\right), 0.96(6 \mathrm{H}, \mathrm{s}$,
$\left.\mathrm{CH}_{3}-23, \mathrm{CH}_{3}-27\right), 0.81\left(3 \mathrm{H}, \mathrm{s}, \mathrm{CH}_{3}-25\right), 0.79\left(3 \mathrm{H}, \mathrm{s}, \mathrm{CH}_{3}-24\right)$, $0.73\left(3 \mathrm{H}, \mathrm{s}, \mathrm{CH}_{3}-28\right) .{ }^{13} \mathrm{C}$ NMR $\left(\mathrm{CDCl}_{3}, 100 \mathrm{MHz}\right): \delta 218.4$ (C-3), 151.1 (C-20), 109.6 (C-29), 55.1 (C-5), 49.9 (C-9), 48.4 (C-18), 48.1 (C-19), 47.5 (C-4), 43.2 (C-17), 43.1 (C-14), 40.9 (C-8), 40.1 (C-22), 39.8 (C-1), 38.3 (C-13), 37.0 (C-10), 35.7 (C-16), 34.3 (C-2), 33.7 (C-7), 29.9 (C-21), 27.6 (C- 15), 26.8 (C-23), 25.3 (C-12), 21.6 (C-11), 21.2 (C-24), 19.8 (C-6), 19.5 (C-30), 18.2 (C-28), 16.1 (C-25), 15.9 (C-26), 14.6 (C-27).

Fraction E $(170 \mathrm{mg})$ was subjected to silica gel column chromatography using a hexane-EtOAc gradient to afford 92 fractions. Subfractions $E_{27}-E_{30}(20 \mathrm{mg})$ were combined and subjected to preparative TLC to yield tonantzitlolone $\mathrm{A}(7,8 \mathrm{mg})$ as colorless crystals (from acetone). Rf 0.59 (hexane-EtOAc, 85:15), mp 172-173 ${ }^{\circ} \mathrm{C}$. EIMS $m / z$ (\% rel): $464\left(\mathrm{M}^{+}, 25\right), 446$ (29), 364 (12), 350 (10), 180 (25), 126 (25), 97 (100), 69 (65). ${ }^{1} \mathrm{H} \mathrm{NMR}\left(\mathrm{CDCl}_{3}, 400 \mathrm{MHz}\right)$ and ${ }^{13} \mathrm{C} \mathrm{NMR}\left(\mathrm{CDCl}_{3}, 100 \mathrm{MHz}\right)$, see Table 1. Subfractions $\mathrm{E}_{38}-\mathrm{E}_{47}$ were combined and the residue $(29 \mathrm{mg}$ ) was subjected to preparative TLC to yield sitostenone (3, $9 \mathrm{mg})$. Rf 0.42, hexane:EtOAc 85:15. ${ }^{1} \mathrm{H} \mathrm{NMR}\left(\mathrm{CDCl}_{3}\right.$, $400 \mathrm{MHz}$ ): $\delta 5.72(1 \mathrm{H}, \mathrm{s}, \mathrm{H}-4), 1.18(3 \mathrm{H}, \mathrm{s}, \mathrm{H}-19), 0.92(3 \mathrm{H}$, d, $J=8 \mathrm{~Hz}, \mathrm{H}-21), 0.85(3 \mathrm{H}, \mathrm{s}, \mathrm{H}-29), 0.83(3 \mathrm{H}, \mathrm{d}, J=4 \mathrm{~Hz}$, $\mathrm{H}-26), 0.81(3 \mathrm{H}, \mathrm{s}, \mathrm{H}-27), 0.71(3 \mathrm{H}, \mathrm{s}, \mathrm{H}-18) .{ }^{13} \mathrm{C} \mathrm{NMR}\left(\mathrm{CDCl}_{3}\right.$, $100 \mathrm{MHz}): \delta 199.91$ (C-3), 171.9 (C-5), 123.9 (C-4), 56.7 (C-1), 56.2 (C-14), 56.0 (C-17), 54.0 (C-9), 45.97 (C-24), 42.5 (C-13), 39.8 (C-12), 38.8 (C-10), 36.3 (C-20), 35.8 (C-8), 34.1 (C-22), 34.0 (C-7), 33.1 (C-6), 32.2 (C-2), 29.3 (C-23), 28.4 (C-16), 26.2 (C-25), 24.3 (C-15), 23.21 (C-28), 21.2 (C-11), 19.97 (C-27), 19.2 (C-19), 18.9 (C-21), 17.54 (C-26), 12.1 (C-18, C-29).

Fraction F (440 mg) was rechromatographed over silica gel using hexane-EtOAc elution system to obtain 35 eluates. Subfractions $\mathrm{F}_{12}-\mathrm{F}_{18}(64 \mathrm{mg})$ were combined and rechromatographed over silica gel eluting with hexane-EtOAc gradient system, and some fractions were joined and further purified by preparative TLC to yield lupeol $(\mathbf{1}, 19 \mathrm{mg}$ ). Rf 0.40 (hexane-EtOAc, 85:15). From subfractions $\mathrm{F}_{24}-\mathrm{F}_{29}$ was obtained a solid that was characterized by ${ }^{1} \mathrm{H}$ NMR as a 4.3:1 mixture of $\beta$-sitosterol (4) and stigmasterol (5) (72 mg), Rf 0.26, hexane-EtOAc, 85:15. Sequential recrystallizations from acetone-di-isopropyl ether-hexane allowed the purification of the compounds.

From fraction $\mathrm{H}$ was obtained a solid which was purified by repeated recrystallizations from methanol- $\mathrm{CH}_{2} \mathrm{Cl}_{2}$-di-isopropyl ether, affording a white amorphous solid that was characterized by its spectroscopic constants and by chromatographic comparison with an authentic sample as $\beta$-sitosteryl- $\beta$-D-glucopyranoside (6, $38 \mathrm{mg})$. Rf 0.31, $\mathrm{CH}_{2} \mathrm{Cl}_{2}-\mathrm{MeOH}, 9: 1$ [23].

\section{Cytotoxicity Assay}

The cytotoxicity of pure compounds was determined against a number of tumor cells by proliferation assay using the colorimetric method of the sulforhodamine B (SRB, protein binding dye). Cell lines of human tumors, central nervous system (U251), prostate (PC-3), leukemia (K562), colon (HCT-15), breast (MCF-7) and lung (SKLU) were provided by the 
National Cancer Institute (USA). Colored solutions were extracted and optical densities were read on an Ultra Reader of Microplate (Elx 808, Bio-Tek Instruments, Inc.) at wavelength of $515 \mathrm{~nm}$.

\section{X-ray crystallographic analysis of 7}

$\mathrm{X}$-ray structural analysis was achieved on a Bruker D8 Venture automatic diffractometer with a CCD area detector at 173(2) $\mathrm{K}$ using helios multilayer mirror $\mathrm{Cu} \mathrm{K} \alpha$ radiation $(\lambda=$ $1.54178 \AA$ ). The structure was solved by direct methods and refined by full-matrix least-squares on $F^{2}$ using the program SHELXS-2014 (Bruker, 2014). The crystal data can summarized as follows: empirical formula $\mathrm{C}_{26} \mathrm{H}_{40} \mathrm{O}_{7}$; formula weight $464.58 \mathrm{amu}$; colorless prism, crystal system orthorhombic, crystal size $0.278 \times 0.175 \times 0.098 \mathrm{~mm}$, space group $P 2_{1} 2_{1} 2_{1}$, $Z=4, a=10.1588(2) \AA, b=10.2763(2) \AA, c=25.2894(6) \AA$, $\mathrm{V}=2640.08(10) \AA^{3}, D_{\text {calcd }} 1.171 \mathrm{Mg} / \mathrm{m}^{3} ; F(000)=1012 ; \mu=$ $0.681 \mathrm{~m}^{-1} ; 19338$ collected reflections $\left(3.49^{\circ} \leq \boldsymbol{\theta} \leq 68.27^{\circ}\right)$, $-11<=\mathrm{h}<=12,-12<=\mathrm{k}<=7,-30<=1<=30 ; 4827$ independent reflections $\left(R_{\text {int }}=0.0615\right)$; goodness-of-fit on $F^{2}$ is 1.148 , final $R$ indices for $I>2 \sigma(I), R_{1}=0.066, w R_{2}=0.174, R$ indices for all data $R_{1}=0.0777, w R_{2}=0.1873$; refining 331 parameters and 83 restraints; the largest difference peak and hole was 0.359 and -0.232 e. $\AA^{-3}$; completeness to $\boldsymbol{\theta}\left(25.24^{\circ}\right) 99.8 \%$, absorption correction was not applied. Selected crystallographic data are available as supplementary material of this article. Complete crystallographic data were deposited at the CCDC, deposition number 1432773. These data can be obtained free of charge via http://www.ccdc.cam.ac.uk/conts/retrieving.html.

\section{Acknowledgments}

The authors thank SENESCYT (Ecuador), CONACYT (México-288423), UNAM (DGAPA PAPIIT IG 200514), and Programa de Maestría y Doctorado en Ciencias Químicas, UNAM, for financial support. We also thank María Teresa Ramírez Apan, María de los Ángeles Peña González, Rocío Patiño, Antonio Nieto Camacho, Luis Velasco, Javier Pérez Flores (Instituto de Química de la UNAM) for technical assistance. This work is dedicated to Dr. Héctor Rasgado-Flores (Rosalind Franklin University of Medicine and Science, Chicago, USA) on the occasion of his musical composition "Suite of the Elements" written for the International Year of Chemistry (2011).

\section{References}

1. Al Muqarrabun, L.M.R.; Ahmat, N.; Aris, S.R.S. A review of the medicinal uses, phytochemistry and pharmacology of the genus Sapium. J. Ethnopharmacol. 2014, 155, 9-20.

2. The Plant List. http://www.theplantlist.org/ (accessed on 19/11/2016).

3. Devkota, H.P.; Basnet, P.; Yahara, S. Diterpene esters and phenolic compounds from Sapium insigne (Royle) Benth. ex Hook fil. Chem. Pharm. Bull. 2009, 57, 1289-1291.
4. Devkota, H.P.; Basnet, P.; Yahara, S. A new phenolic compound, 4-dehydrochebulic acid-1,6-dimethyl ester from Sapium insigne leaves. J. Nat. Med. 2010, 64, 191-193.

5. Huang, S.; Fujioka, T.; Yoshida, M.; Ishimaru, K. A new chalcone glycoside from Sapium sebiferum. J. Nat. Med. 2007, 61, 339-341.

6. Fu, R.; Zhang, Y.; Guo, Y.; Chen, F. Chemical composition, antioxidant and antimicrobial activity of Chinese tallow tree leaves. Ind. Crops Prod. 2015, 76, 374-377.

7. Taylor, S.E.; Gafur, M.A.; Choudhury, A.K.; Evans, F.J. Nitrogen-containing Phorbol Derivatives of Sapium indicum. Phytochemistry 1981, 20, 2749-2751.

8. Chumkaew, P.; Karalai, C.; Ponglimanont, C.; Chantrapromma, K. Antimycobacterial Activity of Phorbol Esters from the Fruits of Sapium indicum. J. Nat. Prod. 2003, 66, 540-543.

9. Liu, H.B.; Zhang, H.; Yu J.H.; Xu C.H.; Ding, J.; Yue, J.M. Cytotoxic Diterpenoids from Sapium insigne. J. Nat. Prod. 2012, 75, $722-727$.

10. Arbain, D.; Byrne, L.T.; Cannon, J.R.; Patrick, V.A.; White, A.H. (-)-Bukittinggine, the Major Alkaloid of Sapium baccatum. Crystal Structure and Absolute Configuration of Bukittinggine Hydrobromide. Aust. J. Chem. 1990, 43, 185-190.

11. Ahmed, Y.; Sohrab, Md.H.; Al-Reza, S.M.; Tareq, F.S.; Hasan, C.M.; Sattar, M.A. Antimicrobial and cytotoxic constituents from leaves of Sapium baccatum. Food Chem. Toxicol. 2010, 48, 549-552.

12. Al Muqarrabun, L.M.R.; Ahmat, N.; Aris, S.R.S.; Norizan, N.; Shamsulrijal, N.; Yusof, F.Z.M.; Suratman, M.N.; Yusof, M.I.M.; Salim, F. A new triterpenoid from Sapium baccatum (Euphorbiaceae). Nat. Prod. Res. 2014, 28, 1003-1009.

13. Siems, K.; Jakupovic, J.; Castro, V.; Poveda, L. Rigidol, an unusual diterpene from Sapium rigidifolium. Phytochemistry 1993, 33, 1465-1468.

14. Woldemichael, G.M.; Lugo, M.T.G.; Franzblau, S.G.; Wang, Y.; Suarez, E.; Timmermann, B.N. Mycobacterium tuberculosis growth inhibition by constituents of Sapium haematospermum. J. Nat. Prod. 2004, 67, 598-603.

15. Yang, P.; Kinghorn, A.D. Coumarin constituents of the chinese tallow tree (Sapium sebiferum). J. Nat. Prod. 1985, 48, 486-488.

16. Flores, J.S.; Vermont-Ricalde, R. The Secretions and Exudates of Plants Used in Mayan Traditional Medicine. J. Herbs Spices Med. Plants 1996, 4, 53-59.

17. García-Méndez, M. C.; Macías-Ruvalcaba, N. A.; Lappe-Oliveras, P.; Hernández-Ortega, S.; Macías-Ruvalcaba, M. L. Phytotoxic Potential of Secondary Metabolites and Semisynthetic Compounds from Endophytic Fungus Xylaria feejeensis Strain SM3e-1b Isolated from Sapium macrocarpum. J. Agr. Food Chem. 2016, 64, 4255-4263.

18. Burns, D.; Reynolds, W.F.; Buchanan, G.; Reese, P.B.; Enriquez, R.G., Assignment of ${ }^{1} \mathrm{H}$ and ${ }^{13} \mathrm{C}$ spectra and investigation of hindered side-chain rotation in lupeol derivatives. Magn. Reson. Chem. 2000, 38, 488-493.

19. Carpenter, R.C.; Sotheeswaran, S.; Sultanbawa, M.U.S. ${ }^{13}$ CNMR studies of some Lupane and Taraxerane Triterpenes. Org. Magn. Reson. 1980, 14, 462-465.

20. Greca, M. D.; Monaco, P.; Previtera, L. Stigmasterols from Typha latifolia. J. Nat. Prod. 1990, 53, 1430-1435.

21. Prachayasittikul, S.; Suphapong, S.; Worachartcheewan, A.; Lawung, R.; Somsak Ruchirawat, S.; Prachayasittikul, V. Bioactive Metabolites from Spilanthes acmella Murr. Molecules 2009, 14, 850-867.

22. Kongduang, D.; Wungsintaweekul, J.; De-Eknamkul, W. Biosynthesis of $\beta$-sitosterol and stigmasterol proceeds exclusively via the 
mevalonate pathway in cell suspension cultures of Croton stellatopilosus. Tetrahedron Lett. 2008, 49, 4067-4072.

23. Kim, D. K.; Lim, J. P.; Kim, J. W.; Park, H. W.; Eun, J. S. Antitumor and Antiinflammatory Constituents from Celtis sinensis. Arch. Pharm. Res. 2005, 28, 39-43.

24. Jasper, C.; Wittenberg, R.; Quitschalle, M.; Jakupovic, J.; Kirschning, A. Total synthesis and elucidation of the absolute configuration of the diterpene tonantzitlolone. Org. Lett. 2005, 7, 479-482.

25. Dräger, G.; Jeske, F.; Kunst, E.; Lopez, E. G., Sanchez, H. V.; Tsichritzis, F.; Kirschning, A.; Jakupovic, J. Tonantzitlolone and other Diterpenes from Stillingia sanguinolenta. Eur. J. Org. Chem. 2007, 5020-5026.

26. Lima, M.A.A.; Lima, J.Q.; Arriaga, A. M. C.; Andrade-Neto, M.; Santiago, G.M.P.; Bezerra, B.P.; Fereira, Y.S.; Veras, H.N.H.; Braz-Filho, R. Constituintes Químicos de Sebastiania macrocarpa Muell. Arg. (Euphorbiaceae). Quim. Nova 2009, 32, 348-353.

27. Techer, S.; Girard-Valenciennes, E.; Retailleau, P.; Neyts, J.; Guéritte, F.; Leyssen, P.; Litaudon, M.; Smadja, J.; Grondin, I. Tonantzitlolones from Stillingia lineata ssp. lineata as potential inhibitors of chikungunya virus. Phytochemistry Lett. 2015, 12, 313-319.

28. Napolitano, J. G.; Gavín, J. A.; García, C.; Norte, M.; Fernández, J. J.; Hernández Daranas, A. On the Configuration of Five-Membered Rings: A Spin-Spin Coupling Constant Approach. Chem. Eur. J. 2011, 17, 6338-6347.

29. Dräger, G.; Jeske, F.; Kunst, E.; Lopez, E.G.; Sanchez, H.V.; Tsichritzis, F.; Kirschning, A.; Jakupovic, J. Tonantzitlolone and other Diterpenes from Stillingia sanguinolenta. Eur. J. Org. Chem. 2007, 6128.

30. Wittenberg, R.; Beier, C.; Dräger, G.; Jas, G.; Jasper, C.; Monenscheina, H.; Kirschning, A. Towards the total synthesis of tonantzitlolone, preparation of key fragments and the complete carbon backbone. Tetrahedron Lett. 2004, 45, 4457-4460.

31. Jasper, C.; Adibekian, A.; Busch, T.; Quitschalle, M.; Wittenberg, R.; Kirschning, A. Total Synthesis of Cyclic Diterpene
Tonantzitlolone Based on a Highly Stereoselective Substrate-Controlled Aldol Reaction and Ring-Closing Metathesis. Chem. Eur. J. 2006, 12, 8719-8734.

32. Busch, T.; Schuster, H.; Kirschning, A. Determination of the absolute configuration of the diterpene tonantzitlolone B. Tetrahedron Lett. 2008, 49, 5273-5275.

33. Monks, A.; Scudiero, D.; Skehan, P.; Shoemaker, R.; Paull, K.; Vistica, D.; Hose, C.; Langley, J.; Cronise, P.; Vaigro-Wolff, A.; Gray-Goodrich, M.; Campbell, H.; Mayo, J.; Boyd, M. Feasibility of a High-Flux Anticancer Drug Screen Using a Diverse Panel of Cultured Human Tumor Cell Lines. J. Natl. Cancer Inst. 1991, 83, 757-766.

34. El-Readi, M.Z.; Hamdan, D.; Farrag, N.; El-Shazly, A.; Wink, M. Inhibition of P-glycoprotein activity by limonin and other secondary metabolites from Citrus species in human colon and leukaemia cell lines. Eur. J. Pharm. 2010, 626, 139-145.

35. Chu, C.W.; Liu, C.M.; Chung, M.I.; Chen, C.Y. Biofuncional Constituents from Michelia compressa var. lanyuensis with Anti-Melanogenic Properties. Molecules 2015, 20, 12166-12174.

36. Olivon, F.; Palenzuela, H.; Girard-Valenciennes, E.; Neyts, J.; Pannecouque, C.; Roussi, F., Grondin, I.; Leyssen, P.; Litaudon, M.; Antiviral Activity of Flexibilane and Tigliane Diterpenoids from Stillingia lineata. J. Nat. Prod. 2015, 78, 1119-1128.

37. Sourbier, C.; Scroggins, B.T.; Mannes, P.Z.; Liao, P.J.; Siems, K.; Wolf, D.; Beutler, J.A.; Linehan, W.M.; Neckers, L. Tonantzitlolone cytotoxicity toward renal cancer cells is $\mathrm{PKC} \theta$-and HSF1-dependent. Oncotarget 2015, 6, 29963-29974.

38. Pfeffer, T. J.; Sasse, F.; Schmidt, Ch. F.; Lakämper, S.; Kirshning, A.; Scholz, T. The natural diterpene tonantzitlolone A and its synthetic enantiomer inhibit cell proliferation and kinesin-5 function. Eur. J. Med. Chem. 2016, 112, 164-170.

39. Martínez-Gordillo, M.; Jiménez-Ramírez, J.; Cruz-Durán, R.; Juárez-Arriaga, E.; García, R.; Cervantes, A.; Mejía-Hernández, R. Los Géneros de la Familia Euphorbiaceae en México. An. Inst. Biol. UNAM 2002, 73, 155-281. 
